\title{
Documentation of Indigenous Knowledge of Agriculture Practices in Rajasthan
}

\author{
Palak Mishra* and Rajendra Rathore \\ Department of Extension Education, Sri KaranNarendra Agriculture University, \\ Jobner, Jaipur India \\ *Corresponding author
}

\section{A B S T R A C T}

\begin{tabular}{|l|}
\hline Ke y w o r d s \\
$\begin{array}{l}\text { Indigenous } \\
\text { practices, } \\
\text { documentation }\end{array}$ \\
\hline Article Info \\
\hline $\begin{array}{l}\text { Accepted: } \\
\text { 05 April } 2020 \\
\text { Available Online: } \\
\text { 10 May } 2020\end{array}$ \\
\hline
\end{tabular}

A study was conducted among 240 farmers sampled from Jaipur and Ajmer district of Rajasthan state. Indigenous practices were documented the interview schedule regarding indigenous knowledge about agriculture practices was developed. The interview schedule was developed by investigator through reviewing the available literature, consulting experts of different discipline of agriculture and by discussing with farmers. Finding of the study revealed that summer ploughing was diploid by highest number of farmers $(92.66 \%)$; seed soaking in water was the most common practice. Diploid by (86.66\%);application of manure the sheep/goat/poultry manure/farm yard manure was universal and all the respondents diploid with this practice; while $(80.41 \%)$ were engaged in basin irrigation; hand weeding $(96.66 \%)$; cow dung cake fumes were the highest i.e. $(57.5 \%)$; use of compost was universal practice i.e. $100 \%$;Use of bamboo stick for threshing purpose (16.25\%).Similarly, on the aspect of use of metal bin is universal method of storage of agriculture produce among the respondents.

\section{Introduction}

The term indigenous knowledge has different connotations such as, traditional knowledge, local knowledge, community knowledge, rural people's knowledge, farmer knowledge. Although the concept has different forms the meaning appears to be synonymous. According to Grenier (1998) indigenous knowledge is the traditional knowledge of the local community existing within and developed around the specific conditions of women and men indigenous to a particular geographical area. Documentation of such practices not only helps in probing the past but also help in bringing to light even fragmentary information on traditional method of our ancestors.

Besides, it would help in preserving for posterity the age old practices that remained unrecorded and undocumented. The documentation of the indigenous agricultural practices was accorded with the consultation 
of literature and by conducting pilot study in the area of investigation. The experts of the relevant fields of agriculture were also consulted to reinforce the selection of identified indigenous agricultural practices. In total 70 indigenous agricultural practices were identified, which encompass the collected mass of data. These practices were further grouped and classified into 9 aspects land preparation, seed treatment practices, application of manure practices, irrigation, weed control practices, plant protection measures, soil fertility management practices, threshing and storage practices followed by the respondents was used.

\section{Land preparation}

Under land preparation practice, it is observed that from table 1 that majority of the respondents $(92.08 \%)$ were engaged in summer ploughing, followed by pata/planking $(87.08 \%)$ and deep ploughing (52.91\%).In Jaipur area $(45.00 \%)$ respondents were engaged in deep ploughing practice followed by summer ploughing $(91.66 \%)$ and pata /planking $(90.00 \%)$, while in Ajmer area 59.16 per cent respondents were engaged in deep ploughing practice followed by $(92.5 \%)$ and $(84.16 \%)$ respondents were engaged in summer ploughing and pata/planking practices respectively. While none of the Jaipur and Ajmer area respondents were found in Direct Seeding practice. The findings confirmed with findings of Karthikeyan, et al., (2006).

\section{Seed treatment}

Under seed treatment it is observed that from table 4.2 (ii) that majority of the respondents $(37.5 \%)$ soaking seeds in cow dung slurry (36.66\% were engaged in seeds soaking in water followed by seed soaking in curd $(16.66 \%)$, treating the seeds with mustard oil $(8.33 \%)$, treating the seeds with turmeric powder $(10.83 \%)$, treating seeds with panchagavya $(27.91 \%)$, treating seeds with beejamrut 15.83 percent, treating the seeds with aak paste $(19.58 \%)$, treating seeds with neem $(35.41 \%)$ and $(30.00 \%)$ seed soaking in cow urine practices.

The table-1 show that in Jaipur area $(85.00 \%)$ respondents were engaged in seeds soaking in water followed by seed soaking in curd $(18.33 \%)$, treating the seeds with mustard oil (9.16\%), soaking seeds in cow dung slurry $(45.00 \%)$, treating the seeds with turmeric powder $(12.5 \%)$, treating seeds with panchgavya $(29.16 \%)$, treating seeds with beejamrut $(19.16 \%)$, treating the seeds with aak paste $(27.5 \%)$, treating seeds with neem $(34.16 \%)$ and $(28.33 \%)$ seed soaking in cow urine practices.

While in Ajmer area (66.25\%) respondents were engaged in seeds soaking in water followed by seed soaking in curd $(16.66 \%)$, treating the seeds with mustard oil $(8.33 \%)$, soaking seeds in cow dung slurry (37.5\%), treating the seeds with turmeric powder $(10.83 \%)$, treating seeds with panchagavya $(27.91 \%)$, treating seeds with beejamrut $(15.83 \%)$, treating the seeds with aak paste $(19.58 \%)$, treating seeds with neem $(36.66 \%)$ and $(31.66 \%)$ seed soaking in cow urine practices.

\section{Application of manure}

Under application of manure it is observed that from table 2 that majority of the respondents $(100 \%)$ were engaged in application of sheep/goat/poultry manure/farm yard manure followed by application of green manuring $(33.75 \%)$, application of neem $(49.16 \%)$, use of mixture of ash $(58.33 \%)$, incorporate crop stubble into the soil $(87.91 \%)$ and $(33.75 \%)$ growing green manure crop practices. 
The table-2 shows that Jaipur area (100\%) respondents were engaged in application of sheep/goat/poultry manure/farm yard manure followed by application of green manuring (14.66\%), application of neem (40.83\%), use of mixture of ash (62.5\%), incorporate crop stubble into the soil $(73.33 \%)$ and (14.66\%) growing green manure crop practices. In Ajmer area (100\%) respondents were engaged in application of sheep/goat/poultry manure/farm yard manure followed by application of green manuring (53.33\%), application of neem $(57.5 \%)$, use of mixture of ash (62.5\%), incorporate crop stubble into the soil $(96.66 \%)$ and $(53.33 \%)$ growing green manure crop practices.

\section{Irrigation}

Under irrigation practices it is observed that from table 2 that majority of the respondents $(80.41 \%)$ were engaged in basin irrigation followed by(48.75\%)furrow irrigation, check irrigation $(36.25 \%)$ and $(10.83 \%)$ strip irrigation practices. While none of the respondents were found in chain pump, dhekli and rahat irrigation practices. In Jaipur area $(89.16 \%)$ respondents were engaged in basin irrigation followed by $(44.16 \%)$ furrow irrigation, check irrigation $(32.5 \%)$ and $(9.16 \%)$ strip irrigation practices. While none of the Jaipur area respondents were found in chain pump, dhekli and rahat irrigation practices.

In Ajmer area (71.66\%) respondents were engaged in basin irrigation followed by $(53.33 \%)$ furrow irrigation, check irrigation(40.00\%) and (12.5\%) strip irrigation practices. While none of the Ajmer area respondents were found in chain pump, dhekli and rahat irrigation practices.

\section{Weed control}

Under weed control practices it is observed that from table 4.2 (v) that majority of the respondents $(96.66 \%)$ were engaged in hand weeding practice followed by $(12.5 \%)$ use of common salt, deep ploughing (90.00\%), burning of weed plant $(42.91 \%)$, pre sowing practice $(69.16 \%)$ and $(62.91 \%)$ early sowing practice. The table-3 show that in Jaipur area $(94.16 \%)$ respondents were engaged in hand weeding practices followed by $(7.5 \%)$ use of common salt, deep ploughing (89.16\%), burning of weed plant $(45.00 \%)$, pre sowing practice $(56.66 \%)$ and $(48.33 \%)$ early sowing practice.

In Ajmer area (99.16\%) respondents were engaged in hand weeding practice followed by $(17.5 \%)$ use of common salt, deep ploughing $(90.83 \%)$, burning of weed plant $(40.83 \%)$, pre sowing practice $(81.66 \%)$ and (77.5\%) early sowing practice.

\section{Plant protection measures practices}

Under plant protection measures practices it is observed that from table 3 that majority of the respondents $(57.5 \%)$ were engaged in cow dung cake fumes followed by $(26.66 \%)$ use of neem extract, use of mustard oil $(5.83 \%)$, use of tulsi extract $(3.75 \%)$, use of garlic extract $(11.25 \%)$, use of castor $(10.00 \%)$, use of hing $(10.41 \%)$, use of tobacco leaves $(9.16 \%)$, smoke $(55.83 \%)$, use of kerosene oil (22.91\%), dusting of ash (39.58\%), Spraying of soap water $(8.33 \%)$ and use of dhatura extract $(14.58 \%)$ respectively.

In Jaipur area $(65.00 \%)$ respondents were engaged in smoke followed by $(17.5 \%)$ use of neem extract, use of mustard oil $(4.16 \%)$, use of tulsi extract $(3.33 \%)$, use of garlic extract $(8.33 \%)$, use of castor $(10.83 \%)$, use of hing $(15.00 \%)$, use of tobacco leaves (14.16\%), cow dung cake fumes(63.33\%), use of kerosene oil (38.33\%), dusting of ash (70.00\%), Spraying of soap water $(11.66 \%)$ and use of dhatura extract (13.33\%) respectively. 
In Ajmer area(77.5\%) were engaged in cow dung cake fumes followed by $(35.83 \%)$ use of neem extract, use of mustard oil $(7.5 \%)$, use of tulsi extract $(4.16 \%)$, use of garlic extract $(14.16 \%)$, use of castor $(9.16 \%)$, use of hing $(5.83 \%)$, use of tobacco leaves $(4.16 \%)$, smoke (46.66\%), use of kerosene oil $(19.16 \%)$, dusting of ash $(43.33 \%)$, Spraying of soap water $(5.00 \%)$ and use of dhatura extract $(15.83 \%)$ respectively.

\section{Soil fertility management practices}

Under soil fertility management practices it is observed that from table 4 that majority of the respondents $(100.00 \%)$ use of compost was engaged in followed by $(63.75 \%)$ Incorporate earthworm in the soil, $(23.33 \%)$ Plantation of Khejri trees, $(71.25 \%)$ Crop rotation, (92.08\%) Summer ploughing, (39.58\%) Dusting of ash, (33.75\%) Green manure, $(20.00 \%)$ Mix clay clods collected from the nearest / tank bed respectively.

The table-4 shows that in Jaipur area $(100.00 \%)$ respondents were engaged in use of compost followed by (61.66\%) Incorporate earthworm in the soil, $(27.5 \%)$ Plantation of Khejritrees $(70.00 \%)$, crop rotation, $(91.66 \%)$ summer ploughing, (35.83\%) dusting of ash, (14.66\%) green manure, (22.5\%) Mix clay clods collected from the nearest / tank bed respectively. In Ajmer area (100.00\%) respondents were engaged in use of compost followed by $(74.16 \%)$ Incorporate earthworm in the soil, $(27.5 \%)$ Plantation of Khejri trees, (72.5\%) Crop rotation, (92.5\%) summer ploughing, (43.33\%) dusting of ash, (53.33\%) green manure, $(17.5 \%)$ Mix clay clods collected from the nearest / tank bed respectively.

\section{Threshing}

Under threshing it is observed that from table4 that majority of the respondents $(16.25 \%)$
Uses of bamboo stick were engaged in followed by (13.75\%) pressing \& crushing the ear head through feet $\&$ hand. While none of the respondents were found in moving bullock on the circle over the crop spread in the threshing floor and moving of cylindrical wooden pulling by bullock over the crop.

In Jaipur area (14.16\%) respondents were engaged in by pressing \& crushing the ear head through feet \& hand and (10.00\%) respondents use of bamboo stick for threshing purpose. While none of the respondents were found in moving bullock on the circle over the crop spread in the threshing floor and moving of cylindrical wooden pulling by bullock over the crop.

In Ajmer area (22.5\%) respondents were engaged in use of bamboo stick for threshing purpose and only (13.33\%) respondents pressing \& crushing the ear head through feet \&hand.Whilenone of the respondents were found in moving bullock on the circle over the crop spread in the threshing floor and moving of cylindrical wooden pulling by bullock over the crop .

\section{Storage}

Under storage it is observed that from table 5 that majority of the respondents $(100.00 \%)$ were engaged in use of metal bin followed by $(52.08 \%)$ respondents use of neem leaves, $(4.58 \%)$ use of mud kothi, $(90.41 \%)$ use of gunny bags, (34.58\%) use of common salt , $(41.25 \%)$ use of ash, $(20.00 \%)$ use of turmeric rhizome $(19.58 \%)$ use plastic bags , $(24.58 \%)$ use wheat bhusa, $(45.83 \%)$ use of mustard oil, $(15.00 \%)$ use of amla leaves and use of dhatura leaves $(5.00 \%)$ respectively.

The table-5 show that in Jaipur area (100\%) respondents were engaged in use of metal bin followed by $(48.33 \%)$ respondents use of neem leaves, $(3.33 \%)$ use of mud kothi, 
$(88.33 \%)$ use of gunny bags, $(33.33 \%)$ use of common salt , (30.83\%) use of ash, (19.16\%) use of turmeric rhizome $(96.66 \%)$ use plastic bags , $(20.00 \%)$ use wheat bhusa, $(29.16 \%)$ use of mustard oil, (10.00\%) use of amla leaves and use of dhatura leaves (4.16\%) respectively. In Ajmer area (100\%) respondents were engaged in use of metal bin followed by $(55.83 \%)$ respondents use of neem leaves, $(5.83 \%)$ use of mud kothi, $(98.33 \%)$ use of gunny bags, $(35.83 \%)$ use of common salt , $(51.66 \%)$ use of ash, $(20.83 \%)$ use of turmeric rhizome $(97.5 \%)$ use plastic bags , $(29.16 \%)$ use wheat bhusa, $(54.17 \%)$ use of mustard oil, (20.00\%) use of amla leaves and use of dhatura leaves (5.83\%) respectively.

Table.1 Distribution of respondents by indigenous practices regarding land preparation and Seed Treatment practices

\begin{tabular}{|c|c|c|c|c|}
\hline S.no. & Indigenous practices & $\begin{array}{c}\text { Jaipur } \\
\text { respondent } \\
(\mathbf{n}=\mathbf{1 2 0})\end{array}$ & $\begin{array}{c}\text { Ajmer } \\
\text { respondent } \\
(n=120)\end{array}$ & $\begin{array}{c}\text { Total } \\
\text { respondent } \\
(\mathrm{N}=240)\end{array}$ \\
\hline & & $\mathbf{F}(\%)$ & $\mathbf{F}(\%)$ & $\mathbf{F}(\%)$ \\
\hline \multicolumn{5}{|c|}{ Land Preparation } \\
\hline $\mathbf{a}$ & Deep Ploughing & $54(45.00 \%)$ & $71(59.16 \%)$ & $127(52.91 \%)$ \\
\hline b & Summer Ploughing & $110(91.66 \%)$ & $111(92.5 \%)$ & $221(92.08 \%)$ \\
\hline c & Pata/Planking & $108(90.00 \%)$ & $101(84.16 \%)$ & $209(87.08 \%)$ \\
\hline \multicolumn{5}{|c|}{ Seed Treatment } \\
\hline $\mathbf{a}$ & Seed soaking in water & $102(85.00)$ & $106(88.33)$ & $88(36.66)$ \\
\hline b & $\begin{array}{l}\text { Soaking of seeds in } \\
\text { curd }\end{array}$ & $22(18.33)$ & $18(15.00)$ & $40(16.66)$ \\
\hline c & $\begin{array}{l}\text { Treating the seeds } \\
\text { with mustard oil }\end{array}$ & $11(9.16)$ & $9(7.5)$ & $20(8.33)$ \\
\hline d & $\begin{array}{l}\text { Soaking seeds in cow } \\
\text { dung slurry }\end{array}$ & $54(45.00)$ & $36(30.00)$ & $90(37.5)$ \\
\hline e & $\begin{array}{l}\text { Treating the seeds } \\
\text { with turmeric powder }\end{array}$ & $15(12.5)$ & $11(9.16)$ & $26(10.83)$ \\
\hline $\mathbf{f}$ & $\begin{array}{l}\text { Treating seeds with } \\
\text { panchagavya }\end{array}$ & $35(29.16)$ & $32(26.66)$ & $67(27.91)$ \\
\hline $\mathbf{g}$ & $\begin{array}{l}\text { Treating seeds with } \\
\text { beejamrut }\end{array}$ & $23(19.16)$ & $15(12.5)$ & $38(15.83)$ \\
\hline $\mathbf{h}$ & $\begin{array}{l}\text { Treating the seeds } \\
\text { with aak paste }\end{array}$ & $33(27.5)$ & $14(11.66)$ & $47(19.58)$ \\
\hline $\mathbf{i}$ & $\begin{array}{l}\text { Treating seeds with } \\
\text { neem }\end{array}$ & $41(34.16)$ & $44(36.66)$ & $85(35.41)$ \\
\hline $\mathbf{j}$ & $\begin{array}{l}\text { Seeds soaking in cow } \\
\text { urine }\end{array}$ & $34(28.33)$ & $45(37.5)$ & $72(30.00)$ \\
\hline
\end{tabular}


Table.2 Distribution of respondents by indigenous practices regarding application of manure and irrigation practices

\begin{tabular}{|l|l|c|c|c|}
\hline S.no. & Indigenous practices & $\begin{array}{c}\text { Jaipur } \\
\text { respondent } \\
(\mathbf{n = 1 2 0})\end{array}$ & $\begin{array}{c}\text { Ajmer respondent } \\
(\mathbf{n = 1 2 0})\end{array}$ & $\begin{array}{c}\text { Total respondent } \\
(\mathbf{N = 2 4 0})\end{array}$ \\
\hline & $\mathbf{s F}(\mathbf{\%})$ & $\mathbf{F}(\%)$ & F (\%) \\
\hline Application of manure & & & \\
\hline a & Application of green manuring & $17(14.66)$ & $64(53.33)$ & $81(33.75)$ \\
\hline b & Application of neem & $49(40.83)$ & $69(57.5)$ & $118(49.16)$ \\
\hline c & Use of mixture of ash & $75(62.5)$ & $75(62.5)$ & $140(58.33)$ \\
\hline d & $\begin{array}{l}\text { Application of sheep/goat/poultry } \\
\text { manure/farm yard manure }\end{array}$ & $120(100)$ & $120(100)$ & $240(100)$ \\
\hline e & Incorporate crop stubbles into the soil & $88(73.33)$ & $116(96.66)$ & $211(87.91)$ \\
\hline f. & Growing green manure crops & $17(14.66)$ & $64(53.33)$ & $81(33.75)$ \\
\hline Irrigation & & & & \\
\hline a & Check Basin & $39(32.5)$ & $48(40.00)$ & $87(36.25)$ \\
\hline b & Furrow irrigation & $11(9.16)$ & $64(53.33)$ & $117(48.75)$ \\
\hline c & Strip irrigation & $107(89.16)$ & $15(12.5)$ & $26(10.83)$ \\
\hline d. & Basin Irrigation & & $86(71.66)$ & $193(80.41)$ \\
\hline
\end{tabular}

Table.3 Distribution of respondents by indigenous practices regarding weed control and plant protection measures practices

\begin{tabular}{|c|c|c|c|c|}
\hline S.no & Indigenous practices & $\begin{array}{c}\text { Jaipur respondent } \\
(\mathrm{n}=120)\end{array}$ & $\begin{array}{c}\text { Ajmer respondent } \\
(n=120)\end{array}$ & $\begin{array}{l}\text { Total respondent } \\
(\mathrm{N}=\mathbf{2 4 0})\end{array}$ \\
\hline & & $\mathbf{F}(\%)$ & $\mathbf{F}(\%)$ & $\mathbf{F}(\%)$ \\
\hline \multicolumn{5}{|c|}{ Weed Control } \\
\hline $\mathbf{a}$ & Hand weeding & 113(94.16) & 119(99.16) & $232(96.66)$ \\
\hline b & Use of Common salt & $9(7.5)$ & $21(17.5)$ & $30(12.5)$ \\
\hline c & Deep ploughing & $107(89.16)$ & $109(90.83)$ & $216(90.00)$ \\
\hline d & Burning weed of plant & $54(45.00)$ & $49(40.83)$ & $103(42.91)$ \\
\hline $\mathbf{e}$ & Pre sowing & $68(56.66)$ & $98(81.66)$ & $166(69.16)$ \\
\hline f. & Early sowing & $58(48.33)$ & $93(77.5)$ & $151(62.91)$ \\
\hline \multicolumn{5}{|c|}{ Plant Protection measures } \\
\hline $\mathbf{a}$ & Use of neem extract & $21(17.5)$ & $43(35.83)$ & $64(26.66)$ \\
\hline b & Use of mustard oil & $5(4.16)$ & $9(7.5)$ & $14(5.83)$ \\
\hline c & Use of tulsi extract & $4(3.33)$ & $5(4.16)$ & $9(3.75)$ \\
\hline d & Use of garlic extract & $10(8.33)$ & $17(14.16)$ & $27(11.25)$ \\
\hline $\mathbf{e}$ & Use of Castor & $13(10.83)$ & $11(9.16)$ & $24(10.00)$ \\
\hline f. & Use of hing & $18(15.00)$ & $7(5.83)$ & $25(10.41)$ \\
\hline g. & Use of tobacco leaves & $17(14.16)$ & $5(4.16)$ & $22(9.16)$ \\
\hline h. & Cow dung cake fumes & $76(63.33)$ & $93(77.5)$ & $138(57.5)$ \\
\hline i. & Use of smoke & $78(65.00)$ & $56(46.66)$ & $134(55.83)$ \\
\hline j. & Use of kerosene oil & $46(38.33)$ & $23(19.16)$ & $55(22.91)$ \\
\hline k. & Dusting of ash & $84(70)$ & $52(43.33)$ & 95(39.58) \\
\hline 1. & Spraying of soap water & 14(11.66) & $6(5.00)$ & $20(8.33)$ \\
\hline m. & Use of dhatura extract & $16(13.33)$ & $19(15.83)$ & $35(14.58)$ \\
\hline
\end{tabular}


Table.4 Distribution of respondents by indigenous practices regarding Soil fertility management and Threshing Practices

\begin{tabular}{|c|c|c|c|c|}
\hline S.no. & Indigenous practices & $\begin{array}{c}\text { Jaipur respondent } \\
(\mathbf{n}=120)\end{array}$ & $\begin{array}{l}\text { Ajmer } \\
\text { respondent } \\
(n=120)\end{array}$ & $\begin{array}{c}\text { Total } \\
\text { respondent } \\
(\mathrm{N}=240)\end{array}$ \\
\hline & & $\mathrm{F}(\%)$ & $\mathbf{F}(\%)$ & $\mathbf{F}(\%)$ \\
\hline \multicolumn{5}{|c|}{ Soil fertility management Practices } \\
\hline $\mathbf{a}$ & $\begin{array}{l}\text { Incorporate earthworm in the } \\
\text { soil }\end{array}$ & $74(61.66)$ & $89(74.16)$ & $153(63.75)$ \\
\hline b & Plantation of Khejri trees & $33(27.5)$ & $33(27.5)$ & $56(23.33)$ \\
\hline c & Crop rotation & $84(70.00)$ & $87(72.5)$ & $171(71.25)$ \\
\hline d & Summer ploughing & $110(91.66)$ & $111(92.5)$ & $221(92.08)$ \\
\hline e & Dusting of ash & $43(35.83)$ & $52(43.33)$ & $95(39.58)$ \\
\hline f. & Green manure & $17(14.66)$ & $64(53.33)$ & $81(33.75)$ \\
\hline g. & Use of compost & $120(100.00)$ & $120(100.00)$ & $240(100.00)$ \\
\hline h. & $\begin{array}{l}\text { Mix clay clods collected from } \\
\text { the nearest / tank bed }\end{array}$ & $27(22.5)$ & $21(17.5)$ & $48(20.00)$ \\
\hline \multicolumn{5}{|c|}{ Threshing } \\
\hline $\mathbf{a}$ & Use of bamboo stick & $12(10.00)$ & $27(22.5)$ & $39(16.25)$ \\
\hline b & $\begin{array}{l}\text { By pressing \& crushing the } \\
\text { ear head through feet } \\
\& \text { hand }\end{array}$ & $17(14.16)$ & $16(13.33)$ & $33(13.75)$ \\
\hline
\end{tabular}

Table.5 Distribution of respondents by indigenous practices regarding Storage practices

\begin{tabular}{|c|c|c|c|c|}
\hline S.no. & Indigenous practices & $\begin{array}{c}\text { Jaipur } \\
\text { respondent } \\
(\mathbf{n = 1 2 0})\end{array}$ & $\begin{array}{c}\text { Ajmer } \\
\text { respondent } \\
(n=120)\end{array}$ & $\begin{array}{c}\text { Total } \\
\text { respondent } \\
(\mathbf{N}=\mathbf{2 4 0})\end{array}$ \\
\hline & & $\mathbf{F}(\%)$ & $\mathbf{F}(\%)$ & $\mathbf{F}(\%)$ \\
\hline \multicolumn{5}{|c|}{ Storage } \\
\hline $\mathbf{a}$ & Use of neem leaves & $58(48.33)$ & $67(55.83)$ & $125(52.08)$ \\
\hline b & Use of mud kothi & $4(3.33)$ & $7(5.83)$ & $11(4.58)$ \\
\hline c & Use of gunny bag & $106(88.33)$ & $118(98.33)$ & $217(90.41)$ \\
\hline d & Use of common salt & $40(33.33)$ & $43(35.83)$ & $83(34.58)$ \\
\hline e & Use of ash & $37(30.83)$ & $62(51.66)$ & $99(41.25)$ \\
\hline f. & $\begin{array}{l}\text { Use of } \\
\text { turmericpowder }\end{array}$ & 23(19.16) & $25(20.83)$ & $48(20.00)$ \\
\hline g. & Use of plastic bags & $116(96.66)$ & $117(97.5)$ & 233(97.08) \\
\hline h. & Use of metal bin & $120(100.00)$ & $118(98.33)$ & $240(100.00)$ \\
\hline i. & Use of wheat bhusa & $24(20.00)$ & $35(29.16)$ & $59(24.58)$ \\
\hline j. & Use of mustard oil & $35(29.16)$ & $65(54.17)$ & $110(45.83)$ \\
\hline k. & Use of amla leaves & $12(10.00)$ & $24(20.00)$ & $36(15.00)$ \\
\hline 1. & Use of dhatura leaves & $5(4.16)$ & $7(5.83)$ & $12(5.00)$ \\
\hline
\end{tabular}


It can be concluded from the above discussion that, the indigenous agricultural practices were fairly good. Agricultural Universities should rationalize and standardize these practices which are eco-friendly, low cost and easily manageable. Further, it needs popularization by the state agriculture universities and state department of agriculture, other concerned departments. This study may motivate the researchers to take up such studies in other areas so that in future a compendium of Indigenous Technical Knowledge could be developed in general in the field of agriculture.

\section{References}

Karthikeyan, C.Veerangavathatham, D. Karpagam, D and Firdouse, S.A, (2009).Traditional storage practices. Indian journal of Traditional Knowledge 8(4): 564-568.

Sharma and Meena (2013). Indigenous technological practices followed by musturd grower in Rajasthan. Journal of Progressive Agriculture, 4(1):109-113.

\section{How to cite this article:}

Palak Mishra and Rajendra Rathore. 2020. Documentation of Indigenous Knowledge of Agriculture Practices in Rajasthan. Int.J.Curr.Microbiol.App.Sci. 9(05): 434-441. doi: https://doi.org/10.20546/ijcmas.2020.905.048 